\title{
Removal of Color, Suspended Solids, COD and Ammonia from Partially Stabilize Landfill Leachate by Using Iron Chloride through Coagulation Process
}

\author{
Nur Shaylinda Mohd Zin, Hamidi Abdul Aziz, Nordin Mohd Adlan, Azlan Ariffin, Mohd Suffian \\ Yusoff, and Irvan Dahalan
}

\begin{abstract}
Sufficient treatment of leachate is vital before it is discharged into receiving water bodies. MLS leachate is characterized as partially stabilized leachate. Therefore, coagulation is a fair treatment to degrade pollutants in MLS leachate. The aim of this study was to evaluate the optimum coagulation conditions of dose and $\mathrm{pH}$ of iron chloride for MLS leachate by using jar test. The influence of iron chloride dose, resulted in percentage removal of SS $(97 \%$ at $1500 \mathrm{mg} / \mathrm{L})$, color $(95 \%$ at $1500 \mathrm{mg} / \mathrm{L}), \mathrm{COD}(66 \%$ at $2000 \mathrm{mg} / \mathrm{L})$ and $\mathrm{NH} 3-\mathrm{N}(13 \%$ at $3500 \mathrm{mg} / \mathrm{L})$. While theaffect of $\mathrm{pH}$, SS $(94 \%$ at $\mathrm{pH6})$, color(95\% at $\mathrm{pH} 6), \mathrm{COD}(66 \%$ at $\mathrm{pH} 6)$ and $\mathrm{NH3}-\mathrm{N}(56 \%$ at pH 6) were observed. Optimum dose and $\mathrm{pH}$ at $1500 \mathrm{mg} / \mathrm{L}$ and 6 were selected for SS, color and COD.Meanwhile,dose 3500 $\mathrm{mg} / \mathrm{L}$ and $\mathrm{pH} 12$ were selected for the optimum coagulation condition for NH3-N removal. Overall, treatment of the MLS leachate by the coagulation process with addition of IC was effective for SS, color and COD but weak in reducing NH3-N.
\end{abstract}

Index Terms-Coagulation, iron chloride, leachate

\section{INTRODUCTION}

Leachate is a byproduct of landfill operation. As water/liquid passes through solid waste, it will carry along the polluted matter and the solid waste liquid. Thus, leachate is considered as high strength wastewater.. Reduction of pollutant level in leachate is crucial, as it has the ability to contaminate natural water resources.

Various treatments that were originated from sewage and water have been used to treat leachate [1]. Leachate is difficult to handle due to variability of its characteristic. Most of the time combinations of various methods are used. Moreover, as landfill ages, the leachate characteristic changes, and the treatment methods also changes. At acidogenic phase, landfill will release large amount of volatile fatty acid content[2]. Leachate produced at acidogenic phase, can be characterized by high BOD $(>10$ $000 \mathrm{mg} / \mathrm{l})$, high ratios of $\mathrm{BOD} / \mathrm{COD}(>0.7)$, acidic $\mathrm{pH}(5-6)$,

Manuscript received Mach 15, 2013; revised May 12, 2013. This work was supported in part by UniversitiSains Malaysia under RUTeam grant.

NurShaylinda Mohd Zin, is with the Universiti Tun Hussein Onn Malaysia, 86400 Parit Raja, Batu Pahat, Johor, Malaysia (e-mail: nursha@uthm.edu.my).

Hamidi Abdul Aziz, is with School of Civil Engineering, Universiti Sains Malaysia, 14300 Nibong Tebal, Penang, Malaysia (e-mail: cehamid@eng.usm.my).

T. C. Nordin Mohd Adlan, is with the School of Civil Engineering, Universiti Sains Malaysia, 14300 Nibong Tebal, Penang, Malaysia (e-mail nordin@eng.usm.my). high concentration of ammonia (500-1 $000 \mathrm{mg} / \mathrm{l})$, and high level of iron, manganese, zinc, calcium and magnesium. At this phase the landfill will produce a strong and unpleasant smell. The most suitable treatment at this phase is the biological method [3].

However,at themethanogenic phase, the organic fraction in leachate will be dominated by the nonbiodegrable(refractory) compounds. It has low COD $(<$ $4000 \mathrm{mg} / \mathrm{l})$, basic $(\mathrm{ph}>7.5)$ and low biodegradability (BOD/COD $<0.1)[4]$. Odour is also reduced to being nonexistent. However, ammoniacal nitrogen continues to be released at high levels in leachate. Inorganic substances such as iron, sodium, potassium, sulphate and chloride continue to dissolve from the landfill for many years to come. During this phase, chemical and physical treatments are best be used.

Coagulation is a conventional chemical and physical treatment process used in most water and wastewater treatment. It involves addition of coagulant into the polluted water under rapid mixing intensity. Addition of coagulant will destabilize the suspended particle, promote agglomeration of floc and finally the floc will settle at the bottom of reactor.

Numerous studies on the application of coagulant for partially stabilized leachate had been reported by various researchers for the pastyears [5-10]. However, no attempt has so far been made in application of Iron Chloride (IC) for Matang Landfill site (MLS). Each site of landfill will produce unique characteristics of leachate. Thus, the performance of IC on MLS will be different from other landfills. This article, evaluating the performance of IC in removing suspended solid (SS), color, chemical oxygen demand (COD) and ammonia (NH3-N) from partially stabilized MLS leachate.

\section{EXPERIMENTAL PROCEDURE}

\section{A. Leachate Sampling and Characterization}

Leachate samples were collected from MLS, located in at $4^{\circ} 49^{\prime} 20.08^{\prime} \mathrm{N}$ and $100^{\circ} 40^{\prime} 44.08^{\prime \prime}$ E near Taiping town in Perak, Malaysia. MLS is equipped with a leachate collection pond. The collection pond acted as a detention pond. Total landfill area of MLS is 12 ha. The landfill received about 300 tons of solid waste daily. Recycling was practiced at site mainly by scavenger. Then the remaining solid waste was dumped on site and covered by local soil.

Sampling procedure was conducted according to 
collection and preservation of samples Method [11]. All samples were collected and immediately transported to the Laboratory and stored in a cold room at $4^{\circ} \mathrm{C}$ to minimize biological and chemical reactions. Prior to analysis, the samples were allowed to return to room temperature. All parameter $\mathrm{s}$ were measured according to APHA (2005) standard method[11].

\section{B. Jar Test}

Coagulation experiments were performed by using(SW6 Stuart, Bibby Scientific Limited, UK). Tests were carried out at room temperature. $\mathrm{NaOH}$ and HCL were used for $\mathrm{pH}$ adjustment. A coagulant was added into the reactor, and rapidly mixed $(250 \mathrm{rpm})$ with $500 \mathrm{ml}$ of leachate for 210 seconds. Then slowly mixed $(50 \mathrm{rpm})$ for 50 minutes and lastly allowed to settle (60 minutes) before supernatant sample were collected by using syringe $3 \mathrm{~cm}$ below the surface of leachate for analysis of the responds of the parameter concentrations.

\section{RESUlt AND DisCUSSIONS}

\section{A. Leachate Characterization}

Table II elucidated the characterization of leachate at range and average value of 16 parameters from MLS. All of heavy metal concentrations are below MEQA (1974) permissible limit except for cadmium. Higher than MEQA (1974) permissible limit were recorded for $\mathrm{BOD}_{5}, \mathrm{COD}, \mathrm{SS}$, NH3-N and Oil \&grease. Regarding to this matter, reduction of pollutant on MLS leachate is important. Based on $\mathrm{BOD} / \mathrm{COD}$ ratio, MLS is categorized as partially stabilized leachate, so chemical and physical methods are suitable for MLS leachate treatment.

\begin{tabular}{|c|c|c|c|c|}
\hline \multirow[t]{3}{*}{ No. } & \multirow[t]{3}{*}{ Parameters } & \multicolumn{2}{|l|}{ Matang } & \multirow[t]{3}{*}{$\begin{array}{l}\text { MEQA } \\
(1974)^{\prime}\end{array}$} \\
\hline & & \multicolumn{2}{|l|}{ Value } & \\
\hline & & Range & Average $^{*}$ & \\
\hline 1 & Temperature $\left({ }^{\circ} \mathrm{C}\right)$ & $27.3-37.4$ & 30.3 & 40 \\
\hline 2 & $\mathrm{pH}$ & $7.9-8.5$ & 7.6 & $6.0-9.0$ \\
\hline 3 & BOD5 (mg/L) & $53-280$ & 146 & 20 \\
\hline 4 & $\mathrm{COD}(\mathrm{mg} / \mathrm{L})$ & $470-1260$ & 828 & 400 \\
\hline 5 & $\begin{array}{l}\text { Suspended solids } \\
(\mathrm{mg} / \mathrm{L})\end{array}$ & $194-1620$ & 407 & 50 \\
\hline 6 & Ammonia-N (mg/L) & $311-1620$ & 868 & 5 \\
\hline 7 & Ferum $(\mathrm{mg} / \mathrm{L})$ & $0-5.4$ & 3.1 & 5 \\
\hline 8 & Turbidity(NTU) & $15-289$ & 112 & - \\
\hline 9 & $\mathrm{BOD} / \mathrm{COD}$ & $0.08-0.39$ & 0.18 & - \\
\hline 10 & True color (ptCo) & $885-6680$ & 3199 & - \\
\hline 11 & $\mathrm{DO}(\mathrm{mg} / \mathrm{L})$ & $0.1-3.03$ & 0.69 & - \\
\hline 12 & Oil and grease $(\mathrm{mg} / \mathrm{L})$ & $2780-21350$ & 7468 & 5 \\
\hline 13 & Cadmium $(\mathrm{mg} / \mathrm{L})$ & $0.08-0.42$ & 0.19 & 0.01 \\
\hline 14 & Nickel (mg/L) & $0.02-0.42$ & 0.16 & 0.2 \\
\hline 15 & Cuprum (mg/L) & $0-0.23$ & 0.13 & 0.2 \\
\hline 16 & Mangan $(m g / L)$ & $0-0.25$ & 0.11 & 0.2 \\
\hline
\end{tabular}

*MEQA: Malaysian Environmental Quality Act 1974.

\#6 samples taken from June- December 2012

\section{B. Influence of Iron Chloride Dose}

Amount of coagulant added into the sample is one of the key factors in determining the efficiency of the coagulation process. Doses of coagulant should be kept sufficient enough to perform at its required efficiency. Overdosing should be avoided, as re-stabilization of particle will occur. Fig. 1 shows the coagulation performance of MLS leachate treatment as a function of coagulant dosage.

Based on the data tabulated in Fig. 1, removal level was ranked as $\mathrm{SS}>$ Color $>\mathrm{COD}>\mathrm{NH} 3-\mathrm{N}$. Highest $\mathrm{SS}$ and color removal by IC was at dose $1500 \mathrm{mg} / \mathrm{L}$ with $97 \%$ and $95 \%$ removal respectively. As for COD, highest removal was recorded at $2000 \mathrm{mg} / \mathrm{L}$ dose. While for $\mathrm{NH} 3-\mathrm{N}$, highest removal obtained by the $3500 \mathrm{mg} / \mathrm{L}$ dose of IC. However, the removal of $\mathrm{NH} 3-\mathrm{N}$ is considered low for all range of dose tested.Comparing the removal of COD, NH3-N and color from partially stabilized leachate of Kulim Landfill Site, $30-70 \%$ were recorded respectively by Zainol et al., at dosed $4500 \mathrm{mg} / \mathrm{L}$ of polyalumium chloride[12].

Control sample was included to observe the difference between leachate with and without addition of IC. Fig. 1, suggested that, addition of ICwas able to remove the aforesaid parameters from MLS leachate. Better performance was recorded for SS, color and COD at dose 1000-2000 mg/L IC. However, reduction of SS, color and COD removal were recorded at a higher dose. Furthermore, a tremendous reduction of removal performance was recorded for color fromthe $2500 \mathrm{mg} / \mathrm{L}$ to the $3000 \mathrm{mg} / \mathrm{L}$ dose. On the other hand, for NH3-N, better removal was recorded at a simultaneous dose. Thus, the IC dose significantly affects the coagulation performance of the MLS leachate.

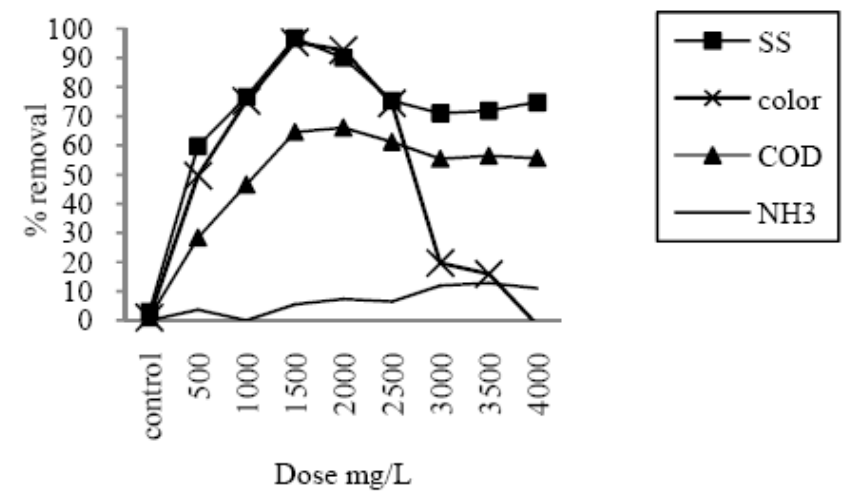

Fig. 2. Treatment of MLS leachate by varying dose of IC

\section{Influence of $p H$}

At optimum $\mathrm{pH}$, the coagulant will produce the most effective hydrolysis species which is responsible for the removal of pollutant. According to Bratby, $\mathrm{pH}$ is one of the important factors during destabilization process[13]. Thus, selected optimum coagulation $\mathrm{pH}$ is crucial for coagulant used in this study.

The effects of $\mathrm{pH}$ on the reduction of responses were investigated (refer Fig. 2). Results indicate that for SS, color and COD removal, higher performance of IC was observed at $\mathrm{pH}$ 6. Since all of these 3 parameters (SS, color and COD) related to organic contents of leachate, same removal trends were recorded for all range of $\mathrm{pH}$ tested. However, the removal rate of SS and color by IC were at par for all range 
of $\mathrm{pH}$ tested. A study by Liu et.al, shows that optimum $\mathrm{pH}$ $(\mathrm{COD}=68 \%$ removal, color $=93 \%$ removal) for $\mathrm{IC}$ in treating leachate is at pH8 with $10 \mathrm{~g} / \mathrm{L}$ dose[14]. While for this study, almost the same removal of COD (66\%) and color $(95 \%)$ at the optimum $\mathrm{pH}$ of 6 was observed. In addition, $94 \%$ of color was recorded by Salina et al, for semi-aerobic leachate at $\mathrm{pH} 4$ at $800 \mathrm{mg} / \mathrm{L} \mathrm{IC} \mathrm{dose[6].}$

While for NH3-N, better performance was recorded at $\mathrm{pH}$ 12. Same removal of NH3-N was recorded by the control sample and leachate at the $\mathrm{pH} 12$. The control sample is the MLS leachate without the adjustment of the $\mathrm{pH}$. As proven, adjustment of the $\mathrm{pH}$, does not significantly affect the NH3$\mathrm{N}$ removal. However for color, $\mathrm{SS}$ and $\mathrm{COD}$, adjustment of the $\mathrm{pH}$ significantly affect the performance of $\mathrm{CI}$ in treating leachate.

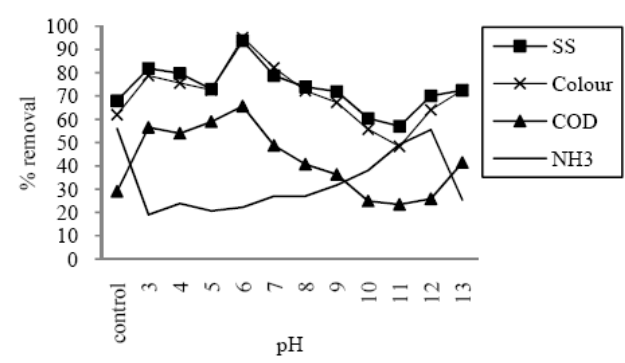

Fig. 2. Treatment of MLS leachate by varying $\mathrm{pH}$ of IC

\section{CONCLUSION}

Coagulation of MLS leachate using IC has been studied. The outcome of the test revealed the ability of IC in degrading pollutant level in leachate. Almost the same removal trends were shown by SS, color and COD under the influence of dose and pH.Optimum dose for SS and color were at the dose of $1500 \mathrm{mg} / \mathrm{L}$. However, for the COD, it was at $2000 \mathrm{mg} / \mathrm{L}$ dose of IC. The same optimum $\mathrm{pH}(\mathrm{pH} 6)$ was recorded for SS, color and COD.NH3-N, shown difference removal trend comparing to other parameters tested. Higher removal of NH3-N, was recorded at a higher dose and $\mathrm{pH}$.

\section{ACKNOWLEDGEMENTS}

The authors greatly acknowledge the UniversitiSains Malaysia for support through RU-Team grant. The authors also wish to acknowledge MajlisPerbandaran Taiping for their assistance during the sampling process.

\section{REFERENCES}

[1] A. Amokrane C. Comel, and J. Veron., "Landfill leachates pretreatment by coagulation-flocculation," Water Research, vol. 31, pp. 2775-2782, 1997.

[2] T. A. Kurniawan, W. H. Lo, and G. Chan., "Physico-chemical treatments for removal of recalcitrant contaminants from landfill leachate," Journal of Hazardous Materials, vol. 129, pp. 80-100, 2006.

[3] S. E. H. Comstock, T. H. Boyer, K. C. Graf, and T. G. Townsend, "Effect of landfill characteristics on leachate organic matter properties and coagulation treatability," Chemosphere, vol. 81, pp. 976-983, 2010.

[4] W. Li, T. Hua, Q. Zhou, S. Zhang, and F. Li, "Treatment of stabilized landfill leachate by the combined process of coagulation/flocculation and powder activated carbon adsorption," Desalination, vol. 264, pp. $56-62,2010$.

[5] M. N. Adlan, P. Palaniandy, and H. A. Aziz, "Optimization of coagulation and dissolved air flotation (DAF) treatment of semiaerobic landfill leachate using response surface methodology (RSM)," Desalination, vol. 277, pp. 74-82, 2011.

[6] H. A. Aziz, S. Alias, M. N. Adlan, Faridah, A. H. Asaari, and M. S. Zahari, "Colour removal from landfill leachate by coagulation and flocculation processes," Bioresource Technology, vol. 98, pp. 218-220, 2007.

[7] S. Ghafari, H. A. Aziz, and M. J. K. Bashir, "The use of polyaluminum chloride and alum for the treatment of partially stabilized leachate: A comparative study," Desalination, vol. 257, pp. 110-116, 2010.

[8] O. S. Leng, "A study on landfill leachate treatment by PACL,Sago Starch and Tapioca Starc, Hymenocallis Liriosme and Aloe Vera as Coagulants," Master, School of Civil Engineering, Universiti Sains Malaysia, Penang, 2010

[9] A. A. Tatsi, A. I. Zouboulis, K. A. Matis, and P. Samaras., "Coagulation-flocculation pretreatment of sanitary landfill leachates," Chemosphere, vol. 53, pp. 737-744, 2003.

[10] P. Palaniandy, M. N. Adlan, H. A. Aziz, and M. F. Murshed., "Application of dissolved air flotation (DAF) in semi-aerobic leachate treatment," Chemical Engineering Journal, vol. 157, pp. 316-322, 2010.

[11] APHA, Standard Methods for the Examination of Water and Wastewater, 21 ed. Washington D.C: American Public Health Association, 2005.

[12] N. A. Zainol, H. A. Aziz, M. S. Yusoff, and M. Umar., "The use of Polyaluminum Chloride for the treatment of Landfill Leachate via Coagulation and Flocculation processes," Research Journal of Chemical Sciences, vol. 3, pp. 34-39, 2011.

[13] J. Bratby, Coagulation and flocculation in water and wastewater treatment, International Water Assn, 2006.

[14] X. Liu, X.-M. Li, Q. Yang, X. Yue, T.-T. Shen, W. Zheng, K. Luo, Y.-H. Sun, and G.-M. Zeng, "Landfill leachate pretreatment by coagulation-flocculation process using iron-based coagulants: Optimization by response surface methodology," Chemical Engineering Journal, 2012.

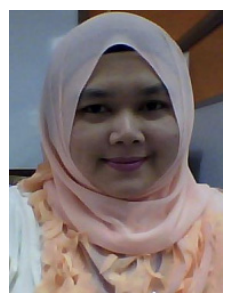

Nur Shaylinda Mohd Zin is a PhD student at the School of Civil Engineering, UniversitiSains Malaysia, and Malaysia. Since 2004 until present, he was associated with UniversitiTun Hussein Onn Malaysia, MALAYSIA (UTHM). She has experience working as an academician since 2004 at Faculty of Civil and Environmental Engineering, UTHM.

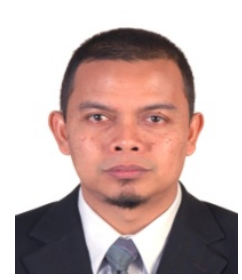

Hamidi Abdul Aziz is a Professor at School of Civil Engineering, Universiti Sains Malaysia, Malaysia (USM). He has a variety of academic and research experience involving teaching, research, consultancy, publication and management. His fields of specialization are water supply engineering, wastewater engineering and solid waste anagement.

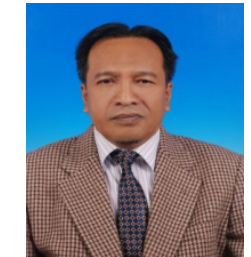

treatment.

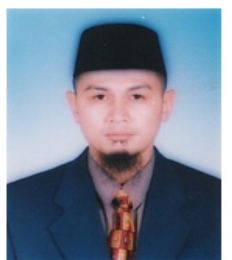

Mohd Nordin Adlan is a Professor at School of Civil Engineering, Universiti Sains Malaysia, Malaysia (USM). He has a variety of academic and research experience involving teaching, research, consultancy, publication and management. His fields of specialization are solid waste and leachate treatment technology, solid waste management and Water and wastewater

Azlan Ariffin is a Professor at School of Materials and Mineral Resources Engineering, UniversitiSains Malaysia, Malaysia (USM). He has a variety of academic and research experience involving teaching, research, consultancy, publication and management. His fields of specialization are Plastic Technology Blending and Modification of Polymer. 


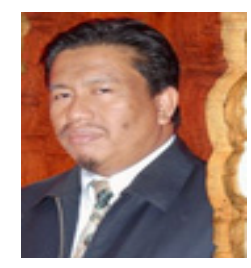

Mohd Suffian Yusuff is an associate proffesor at School Civil Engineering, Universiti Sains Malaysia, MALAYSIA (USM). He has a variety of academic and research experience involving teaching, research, consultancy, publication and management. His fields of specialization are solid waste management and leachate treatment.

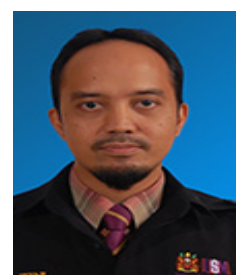

Irvan Dahlan is a senior lecturer at School of Chemical Engineering, Universiti Sains Malaysia, MALAYSIA (USM). He has a variety of academic and research experience involving teaching, research, consultancy, publication and management. is fields of specialization are air pollution engineering, wastewater treatment and enzyme/environmental catalysis. 